\title{
Article \\ Current humanistic values in contemporary urban trends and ideas
}

\author{
Rafał Blazy (0000-0002-0466-8855) 1,*, Mariusz Łysień (0000-0002-7500-4036) ${ }^{1}$ and Jakub Dudek (0000-0002-1541-9512)
}

1 ,
1 Department of Spatial Planning, Urban and Rural Design. Faculty of Architecture; Cracow Cracow Univer- sity of Technology, Faculty of Architecture, Warszawska 24, 31-155, Cracow, Poland; rafal.blazy@pk.edu.pl (R.B.); mariusz.lysien@pk.edu.pl (M.Ł.); jakub.dudek@pk.edu.pl (J.D.)
* Correspondence: rafal.blazy@pk.edu.pl (R.B.)

\begin{abstract}
The article discusses the role of humanistic values in the contemporary configuration of cities. Today's times put us in a privileged position as we can observe deep and clear changes happening very quickly. Visible changes are reflected not only in society and culture, but also in the space of developing cities, towns, and metropolises. While characterizing contemporary urban trends and ideas, the philosophical trends that contribute to them and the values on which they are based were discussed. Corrections are also shown, which usually start with slight dissonances and initially slight differences in the content of theses, and as a result lead to completely different views on the world. Contemporary determinants of postmodernism, deconstructivism, ecological ideas, sustainable development, social integration and participation, high-tech, digital, and smart city are discussed in detail.
\end{abstract}

Keywords: values, humanities, idea, urbanism, city, sustainable development

\section{Introduction}

In post-Kantian science and philosophy [1] [2] [3] human values are a priori and fundamental factor determining human behavior. This applies to both the way an individual functions and the way his or her basic mental, bio-logical and social needs are satisfied. Values are strongly and inextricably linked with every human being. In the light of contemporary research, values are considered the basic, or even primary link of processes related to human choices [4]. Their impact on social life is extremely deep and significant role is primarily that they determine to some extent our future. In this context, a common concern for specifying currently recognized goods (values) is in the broadly understood general humanity interest, because they will determine the possible scenarios of urban development. The historical "declines" of civilization related to the abandonment of previously cherished parities of values suggest that a similar dramatic situation with the decline of European cultural heritage is possible today. Therefore, the question arises: is a very strong revaluation, occurring in Europe nowadays, the precursor to subsequent changes in the urban space [5]?

The publication attempts to determine the impact of recognized values on the city at various stages of development, taking the 20th century and present day as the time frame. It shows the relationship of values with the city in various aspects, leading from the past to the present [6]. The world of values is ambiguous and complicated, however, it gives a kind of new perspective on the city. Despite the fact that the city was the subject of considerations already in the times of Plato [7] and Aristotle [8], over the centuries, the concept of "city philosophy" was not developed. There are no studies that would explain the absolutely primal and basic ideas of the city's formation [9]. Therefore, there is no clear vision of what kind of being the city is and what is this being striving for. Thus, we also do not have 
an answer to the question of what is the ultimate reason for the existence of a city and what is a city in its definition. At the same time, it is possible to indicate specific philosophical trends that are the basis for the values visible in contemporary and past urban trends and ideas. This is what became one of the goals of this study.

\section{Introduction to the present day - functionalism and modernism}

In the interwar period, the international style was the dominant feature of the architectural scene. The name of this style very accurately reflects the fact that in place of the nineteenth-century diversity and apparent chaos, a uniform and easily recognizable de-sign has emerged, used in Europe and America, and partly in Asia. The interwar period was characterized by the search for a secure, common foundations - the principles and values for the most developed countries of the world.

The very word "functionalism" defines and characterizes the then aspirations and attitude in architecture to rationalize the way of thinking. It is assumed that the style was initiated by American architects Louis Henry Sullivan and Frank Lloyd Wright. "Form follows function" - this quoted sentence of Sullivan [10] gave rise to the basis of functionalism.

Following this lead, the designers searched for the basic principles of architecture and urbanism in the belief that new architecture is an inevitable and logical product of the intellectual and technical conditions for the development of the new era. An important event was the establishment in 1928 of the International Congress of Modern Architecture (CIAM - Congrès International d'Architecture Moderne). The activity of this organization, gathering mainly architects and urban planners with socialist views, headed by its secretary general Sigfried Giedion, focused on coordinating work on formulating principles and directions and on solving theoretical and practical tasks and problems, such as social housing and urban environment.

In its assumptions, the modern movement relied on scientific analysis and sought to define standards that could shape "a polite and orderly society." This does not mean that the main promoters and creators of the movement were indifferent to the goals and values of art. Le Corbusier is commonly regarded as the main founder of functionalism. His famous words from Vers une architecture (Towards Architecture, 1923) indicate that he was aware of the necessity of art; "suddenly you touch my heart, you do me good, I am happy and I say: This is beautiful. That is Architecture. Art enters in." [11]. Le Corbusier has repeatedly referred to the human need for beauty. According to him, beauty could be achieved in two ways: through the use of basic forms and proportional geometry, and as a result of functional responsibility; "When a thing satisfies a certain need, it is beautiful ...". [11]. He also believed that architecture is "something that by itself creates happy people." Here we get to the heart of the functionalist creed, which says that the social and human problems observed are largely the result of a false and imperfect environment, and that the human condition can be improved by a new architecture that thus regains its true and fundamental meaning. At the beginning of his program book, Le Corbusier asked: "Architecture or revolution?" [11], and at the very end, after the glorification of architecture, he answered this question: "revolution can be avoided". The elementary forms and strict rules of functionalist architecture can be interpreted as a protest against what architects perceived as devalued themes and academic compositions of historicism.

Functionalism assumed, first of all, "sincerity of facades" and "sincerity of form", which meant that the appropriate form was an expression of the layout and arrangement of the interior. Functionalism also promoted the principle that the primary duty of a de-signer is to visualize the proper functioning of the structure he designed. The aesthetic and compositional content could not interfere with the function. Functionalism subjected the city to the requirements of a single building.

The term "functionalism" covers three slightly different axiological concepts. The first is based on the assumption that only what is utilitarian is beautiful. This approach 
was represented by Socrates, according to Xenophon's account. The second concept assumes that utility is an equal and immanent quality of beauty. Xenophon and Vitruvius were the followers of this theory. The third approach puts utility above other values, beauty alone is not a necessary condition for this relationship. The English philosopher Francis Bacon was a modern follower of this theory [12].

Modernism, from its critique of historicism, partly based on the philosophy of Arthur Schopyenhauer [13] and Friedrick Nietzsche [14] turned to evolutionism, proclaiming universal variability of forms and continuous development; from less to more perfect structures. Drawing to some extent from phenomenology, it questioned the cognizability of things and phenomena. The only knowable reality - an axiom in modernism is development and change. The existence of an enduring substance, principles, and truth are pure fictions.

Modernism is a rather smooth continuation of functionalism. The five points of modern architecture of Le Corbusier and the Athens Charter are considered to be the ideo-logical documents that formed the basis of modernism. One of the terms of modernism is the phrase "modern movement in architecture".

Basically, modernism in urban planning was characterized by the creation of a city based on a new social order. The overriding value was the satisfaction of the inhabitants, which, in the assumption of modernism, was to result from the new standard of living, implemented in new urban structures, subordinated to the values of functionalism implemented by giving cities appropriate functional zones. The second feature was to ensure equal living conditions for the majority of society, assuming the possibility of achieving social justice as one of the overarching values, especially in the cities of communist and socialist countries.

These two values listed seemed to be paramount. It should be emphasized that they were to some extent about happiness and justice. In turn, aesthetics and functionality were then subject to the value of justice which seems to be superior to them. Justice also meant that an attempt was made to ensure equal opportunities and access for residents to specific functions: service, leisure and recreation, which resulted in the idea of a neighborhood unit [15].

The form resulted, as already mentioned, from the values of justice, as well as from logic and functionalism subordinated to a specific vision of equality. An important feature of modernism was the adoption of a fairly precise vision of social, aesthetic and ethical values, treated as the only possible and even ideal. This situation resulted in the unification of the adopted urban solutions, the unification of the style not only in the field of architecture, but also in spatial planning. One of the effects was the standards developed and adopted in Poland in 1974, which took the form of urban standards and guidelines [16] [17].

\section{Postmodernism}

In 1958, Hundertwasser stated that "Functional architecture has proved to be the wrong road to take, similar to painting with a straight-edged ruler (...) in the name of justice, the constructions of Mies van der Rohe, Neutra, the Bauhaus, Gropius, Johnson, Le Corbusier, Loos etc. should be torn down, as they have been outdated for a generation and have become morally unbearable" [18]. At the same time, architects began to experiment with forms drawn from several different styles. This is how postmodernism was created, which is a combination of many different styles, trends and even cultures. Postmodernism grew out of the belief that traditional and modern philosophical concepts were exhausted [19]. Starting, among others, from the crisis of semiotic meanings systems, proclaimed by Jacques Derrida [20] and prophesying the end of man and questioning all uniform systems of values, the supporters of postmodernism allowed hyperrealistic solutions, especially in terms of aesthetics. This trend showed things, models, and systems in an altered reality. At the same time, postmodernism assumed the possibility of creating works and things in an inconsistent and out of context way. One of the 
features of postmodernism is allowing for eclecticism of forms, or actually playing with convention. . Postmodernism departs from the totalitarian features of modernism, being a nod to existentialism, poststructuralism and deconstruction

Postmodernism is a trend that characterizes the contemporary world in a concise but simplified way [21]. On the one hand, in its assumptions it is an extremely open direction - one could say eclectic not only in terms of form, but also in terms of recognized values. On the other hand, as one of the few trends in the field of architecture and urban planning, it took up the subject of determining the meaning in these areas. The idea of postmodernism, based on the principles of freedom, individualisation and freedom of form, results from the assumption of a pluralistic attitude towards universally recognized values, unfortunately along with the denial or distortion of the basic principles.

As a consequence, pluralism results in the lack of clearly adopted principles in the creation, design and shaping of urban tissues, as well as forms and objects in space. Leaving complete freedom and freedom of choice, consequently leads to extremely different solutions; from harmony to disharmony, from organized structure to chaos, from order to anarchy.

a)

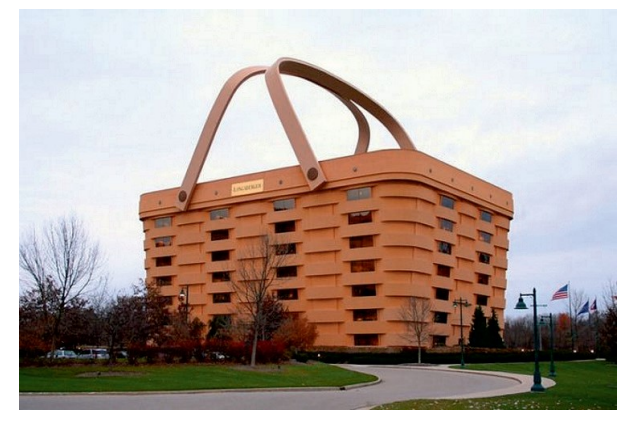

b)

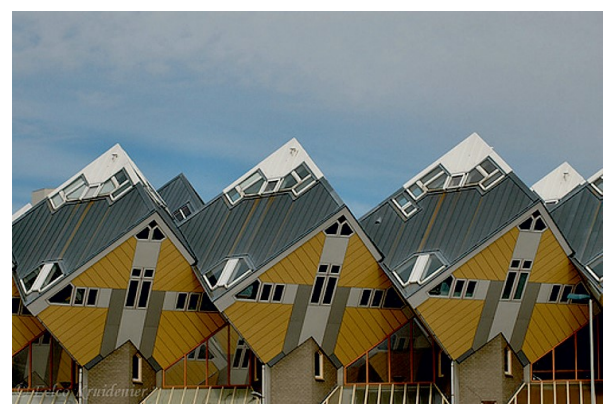

Figure 1. Postmodern projects with extraordinary expressive power - completely detached from the existing context and place: a) Longaberger Basket office building in Newark, Ohio (United States)[22], b) Cubic Houses - Rotterdam (The Netherlands)[23]

On this theoretical basis, postmodernism with its multi-threaded architecture and urban planning assumes multiculturalism, especially pronounced in the multicultural United States of America and Western Europe. However, the acceptance of complete freedom in terms of ethics, then aesthetics and composition, is in fact, in the long run, a negation of order and harmony.

Over the last twenty years in contemporary, uniting Europe, the problem of modernism and postmodernism in the field of architecture and urban planning looks as follows: the most visible are the trends related to globalization, which postmodernism does not oppose, and in fact fits into them well and without any resistance. In the Polish reality, interesting for the authors of this publication, in most cases postmodernism is a repetition of forms, assumptions, and sometimes entire objects found in Western Europe [24]. These con-temporary tendencies were very aptly described by Jakub Wujek, who described the above phenomena as the "myth of universality" [25]. This myth is based on the belief that most contemporary architecture, but also urban tissues, can appear in any context, regardless of the identity and geographic location of a given place. 
a)

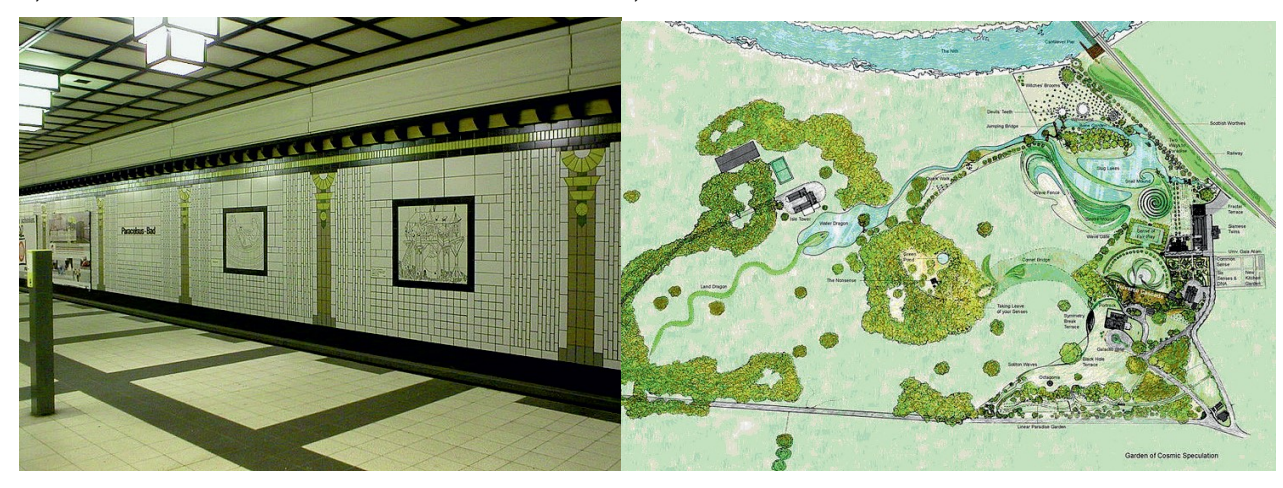

Figure 2. Postmodern realizations of the metro station and the garden: a) Paracelsus-Bad station (Berlin),[26] b) Garden Cosmic Speculation by Charles Jencks - Dumfries (west of Scotland) [27]

Postmodernism has many shades and trends, from the new urbanism represented by brothers Rob and Leon Krier [28], to the natural consequence - deconstructivism.

\section{Deconstructivism}

It seems that deconstructivism is at its source inspired by the theory of chaos and chance, and the calculus of probability; elements that have had a great impact on the shape of modern science, breaking up well-worn patterns and intricately constructed theories, while remaining under the influence of the spontaneous force of the dynamism of life. This dependence can be observed in the architecture and urban planning of deconstructivism, where dynamism results from chaos and disorder, and spontaneity is an inherent component of this mixture.

It should be mentioned that the chaos theory was created thanks to Edward Lorenz, who in 1961 carried out numerical analyzes of weather phenomena. The very theory of chaos in urban planning (in Poland) was taken up by Krzysztof Lenartowicz, distinguishing optimal complexity as the optimum between too simple and too complex spatial organization [29].

The first constructivists published their works in the Oppositions journal (1973-1984). The theories described therein mark the beginning of the decisive division of modernism into two separate trends: postmodernism and deconstructivism. It is assumed that this is a book by Robert Venturi, entitled Complexity and Contradiction in Architecture, which separated deconstructivism from modernism and postmodernism [30]. The publication was a turning point for both postmodernism and deconstructionism. It is a set of reasons against the purity, transparency and simplicity of modernism. At the same time, thanks to Venturi's work, the two main currents of modernism - functionalism and rationalism - have been challenged and de facto abolished as paradigms and re-placed with other, postmodern and deconstructivist views and visions. 
a)

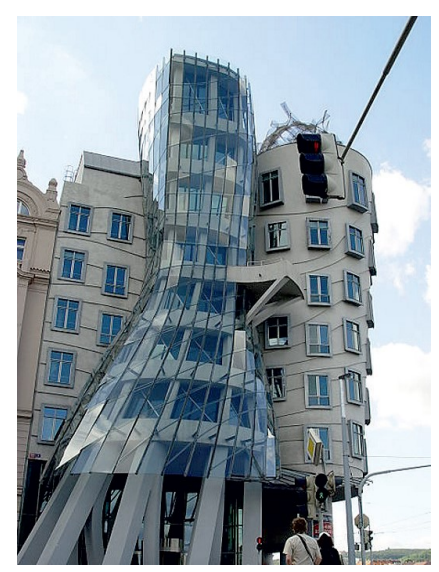

b)

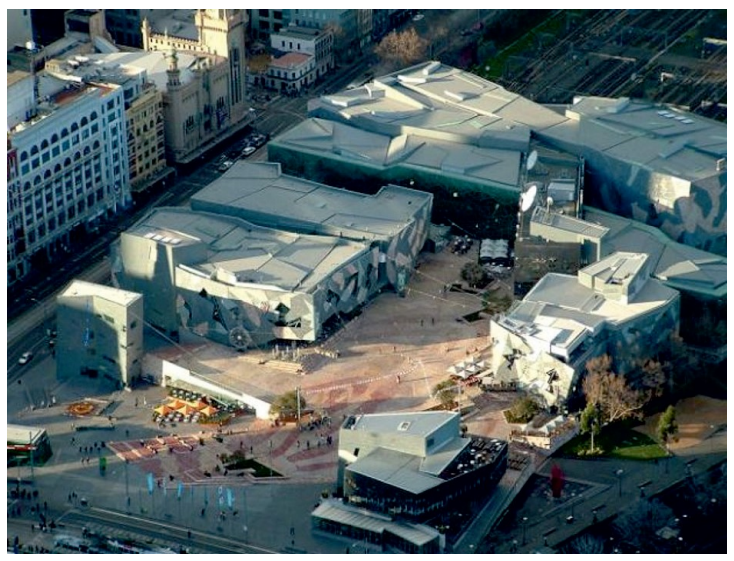

Figure 3. Examples of deconstructive realizations: a) Dancing house designed by Vlado Milunić and Frank Gehry (Prague)[31], b) Deconstructive Federation Square (Melbourne)[31]

Within the scope of progressive deconstructivism nowadays deconstruction can be observed the following areas:

- tradition

- culture

- society

- material and non-material sphere

- form

- structure

- order and harmony

There is a gradual apotheosis (praise, deification) of chaos, expressed most strongly by Tschumi's opinions, publications and realizations [32] (Louis, 1990) the result of which is, among others, more and more scattered city. An example of a deconstructivist realization on an urban scale is the Parc de la Vilette in Paris (1982-1995), which was built on an area of 55 hectares once belonging to a Paris slaughterhouse [33]. To discuss this project, Tschumi invited the French philosopher Jacques Derrida, whose theories had a significant impact on the face of deconstructivism in architecture and urban planning. Jacques Derrida himself is considered the main theorist of the philosophy of deconstructivism [34].

The term deconstruction does not have a precise definition, although it is based on the concept of "destruktion" in Heidegger and on the notion of "the other" in Emmanuel Lévinas [35].

\section{Mobility, cultural and civilization variability - City in the Movement}

Another important feature of the modern city is the mobility and cultural and civilization variability called City in the Movement. Cities from the turn of the 20th and 21st centuries get out of control, they are some kind of autonomous creations. According to Rem Koolhaas, the city is headed for complete decomposition [36] [37]. As a result of this decomposition, a generic city (which also means a city of decay) will arise. Its basic function is to meet the growing needs in terms of constant traffic and movement between three fixed points: an apartment, an office car park and a shopping center. Traditional urban spaces with their centers, boulevards, squares and promenades have become, according to Rem Koolhaas [38] redundant, because the urban activity of residents has been limited to the minimum created by these three places of basic functions: work, living and shopping. This feature also has a significant impact on the standardization of space arrangement and the consolidation of global patterns [39]. 
The street, which as a result of these trends has been fully adapted to the needs of car traffic, currently does not meet the needs of pedestrians in terms of ergonomics in many places, especially in terms of their perception and psychophysical abilities [40]. The subordination to the perspective of car traffic has gradually transformed the city into an area that is aergonomic (anti-ergonomic) and pro-car at the same time [41] [42]. In some sense, the spatial breakdown of the urban structure began when pedestrian communication in the city was replaced by public transport, first in the form of carriages, then horse and electric trams, then buses, trolleybuses and the metro. Then, the popularization of private cars made the city in terms of transport more like structure of separated islands than a continuous organism. Today our cities are more of an archipelago consisting of a set of is-lands (or points) connected together, by rather unstable and discontinuous relationships. The contemporary urban organism is a confused, broken and internally inconsistent structure, but thanks to the current technology it is easily accessible to people [9].

\section{Advanced Technologies}

The high-tech concept first appeared in The Industrial St-le and Source Book for The Home [43]. This text is the result of the Pompidou Center by Renzo Piano and Richard Rogers, realized in 1977 in Paris, on the site of the former Paris halls. It is assumed that high-tech emerged in the 1970s [44]. It is mainly represented by designers such as Norman Foster, Nicholas Grimshaw, Michael Hopkins, Renzo Piano, Richard Rogers, Schweger \& Partners. It must be admitted, however, that in the field of urban planning there are no projects that could be clearly attributed to this style. The distinguishing features of high-tech are: the use of movable structures and various types of installations enabling functional variability of the building or variable arrangement of space, as is the case at Theater Square in Rotterdam, where it is not only a technical element, but also a variable element of space arrangement. Axiological high-tech implementations are based on applied sciences, knowledge and interaction with other scientific disciplines. Overall, the philosophy of technology is a new discipline and has so far not had a clear conceptual and methodological status of its own. One of the strands of this philosophy, perhaps the closest to the concept of high-tech, recognizes that all problems can be solved with the help of new technologies, techniques and their progress [45]. The reference to the ideological approach to technology, presented by, for example, Karl Marx, suggests that technology is a necessary condition to build a proper form of society. As part of this trend, there is an unresolved dispute about the axiological saturation of technology (va-lue-ladennes / value-neutrality of technology), in which an attempt is made to decide whether and in what sense technology (as an artifact) is saturated with values. An extreme form of this approach may be the techno utopism [46] - assuming limitless acceptance of technology.

a)

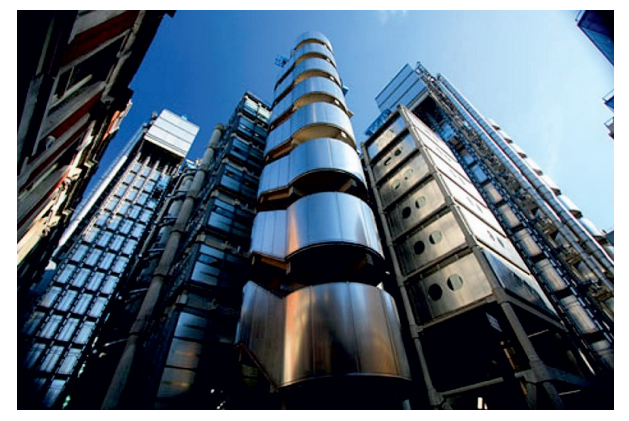

b)

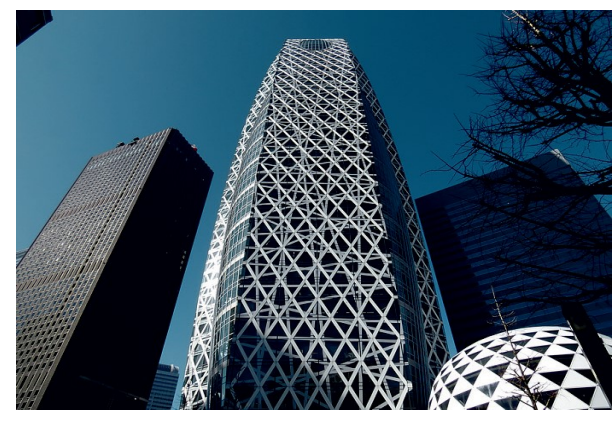

Figure 4. High-tech projects: a) Lloyd office building (Londyn) [47], b) Mode Gakuen Cocoon Tower building (Tokio) [48] 


\section{Ecological ideas}

One of the reasons for paying attention to the natural environment was the Report of the UN Secretary U Thant, published in 1969, entitled Man and the environment. This report is widely regarded as the document that first drew attention to environmental problems. Other important documents are: I and II Clean Air Acts (1970 and 1990) in the United States, The Rome Club Report Limits to Growth (1972, advocating a self-limitation of excessive production and consumption) and the 1st United Nations Environment Conference in Stockholm (1972) where the concept of "sustainable development" was introduced.

In Poland, a number of activities were carried out to improve the quality of the environment in the city. Particularly noteworthy are the solutions proposed in the 1960s for Oświęcim, and later for Tarnów, implemented as part of projects led by prof. Tadeusz Bartkowicz and prof. Barbara Bartkowicz [49]. These projects were an attempt to counter the normative approach to protection zones and a shift towards real problem solving. As a system solution, the introduction of green belts related to the proper ventilation of the area and continuity of ecosystems.

In general, ecological values assume that man is connected back with nature [50]. In terms of ecology, the city is treated as a comprehensive, complementary ecosystem. This trend is aimed at shaping man in such a way that one of his main values is respect for the natural environment. Human freedom in the ecological perspective is not an absolute value and should be subordinated to the creation of a world compatible with the laws of nature. Often ecological values seem to be superior to the structure of the city, and sometimes even to human needs. Indirectly, ecological values influence ethical values, which over time adapt to ecological requirements. The city's shape is mostly influenced by its ecological values, which results from the use of pro-ecological solutions [51]. Aesthetics (aesthetic values) are subordinated to ecological values. Some authors also note the beauty of the natural world, nature, or beauty and harmony in general, but especially in combination with nature.

Respect for the laws of nature is a general assumption accompanying the emergence of ecological cities [52]. This law presupposes that man cannot make excessive use of nature and should strive for ecological balance in his actions. It is also characteristic to think about the future in terms of the resources and impacts of the current economy, with the dominant approach being that natural resources should be left to future generations [53]. The priority reduction of costs related to the use of energy prompts an attempt to search for renewable energy sources.

a)

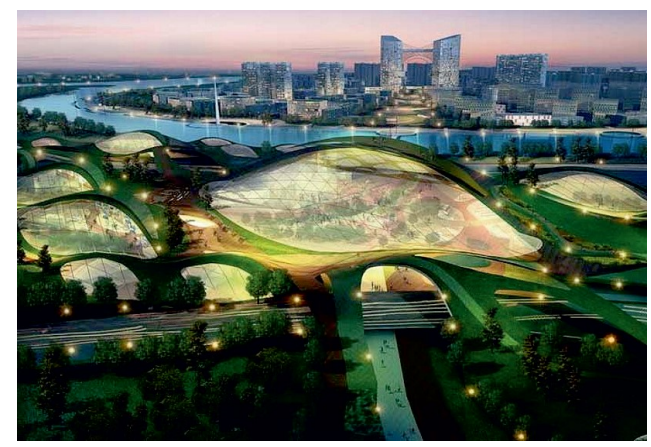

b)

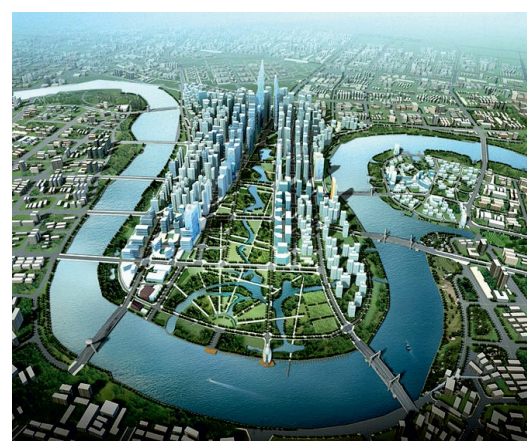

Figure 5. Examples of green cities in China: a) Tiencin [54], b) Tianjin Eco City [55] 
A trend that fits well with the idea of ecological cities is emphasizing the value of local ties as the natural social environment of human life. This view is conducive to the development of a socially friendly district and the perception of the city as a community [56].

The basic directions of eco-philosophy are:

- deep philosophy,

- $\quad$ eco-feminism [57],

- $\quad$ practical philosophy of nature.

\section{The idea of balancing development}

The only reasonably stabilized idea of a city in the 20th century, which was formed at the turn of the 70s and 80s, is the idea of balancing development, in other words about sustainable development. The Chair of the World Commission on Environment and Development, Gro Harlem Brundtland, together with her team, prepared and published the report Our Common Future in April 1987. It contained an innovative concept of sustainable development. The document also became a strong incentive for the 1992 Earth Summit (United Nations Conference on Environment and Development). The summary of the summit in Rio de Janeiro was the publication of a 500-page programming document called Agenda 21. This text is primarily a catalog of environmental goals necessary to achieve in the 21st century, along with a description of how to implement sustainable development programs.

Sustainable development is primarily an attempt to search for many important elements in the development process in order to harmoniously coexist, cohabitate and cooperate [58]. In some cases, however, it seems that individual issues are beginning to dominate, and the rest are obscured by, for example, excessive environmental ecology, implemented at the expense of human ecology, i.e. the primacy of development and economy, at the expense of promoting and respecting the environment. It seems that sustainable development is the most appropriate trend, but without specifying an approximate hierarchy of values, it can lead to distortions understood as a shift of emphasis to elements and issues that are not the most important [59]. The weakness of this position is that it can be explained by respect for different values that may obscure the most important problems and, consequently, lead to wrong solutions. The lack of an unambiguous definition of this concept causes that it is very broad and may contain completely contradictory interpretations, and sometimes even erroneous.

Terms such as sustainable transport, sustainable development, sustainable location policy are often used because of their positive message resulting, as it were, from the prefix of the word sustainable, but what is behind their content is often vague and indefinite.

According to Andrzej Papuziński, the pragmatic philosophy of sustainable development is based on certain assumptions:

1. ontological - man occupies a unique place in the universe, which in turn gives him the right to treat nature as his environment and allows him to relate to it through the prism of his existence, good, interests, needs and desires;

2. anthropological - man is a social being, and therefore can only be fully fulfilled in a group;

3. axiological - the most important value is solidarity with other people, such as family, friends, colleagues, neighbors, etc., current and future generations;

4. historical philosophy - humanity is predestined to development and progress in the course of the cultural process of human self-improvement [60].

The primary goal of sustainable development is the balance between economic growth and the state of the environment and the possibility for society to achieve a high quality of life [61]. To achieve this, philosophy proposes to correct the existing axiological system in the direction of: 
- greater respect for the value of quality of life (measured by parameters such as freedom, equality, work, interpersonal solidarity),

- universal access to basic natural and environmental goods at the expense of the value of quality of life (measured by the amount of material consumption), introduction of mechanisms conducive to saving raw materials and energy and reducing the amount of unused waste.

a)

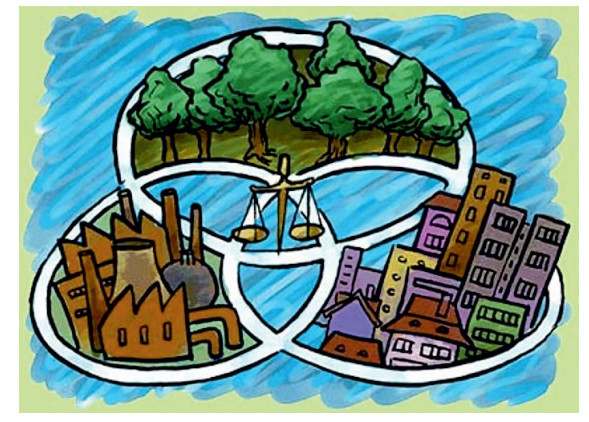

b)

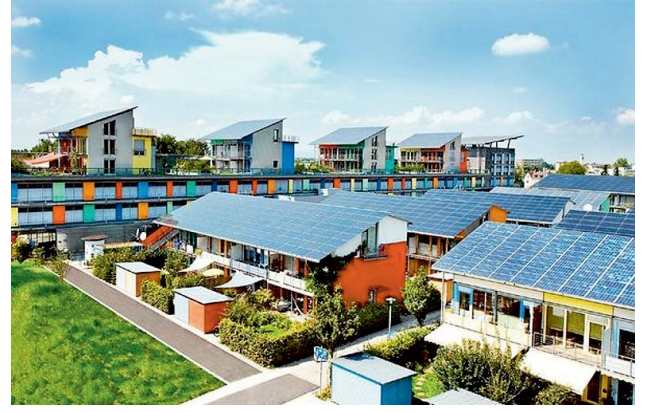

Figure 6. a) Graphical representation of the principle of sustainable development in the city [62], b) a combination of the values of sustainable development and the eco-town in the Friborg-Vauban district [63]

\section{metropolis o

\section{Circles of Sustainability ${ }^{1}$ \\ Urban Profile Process}

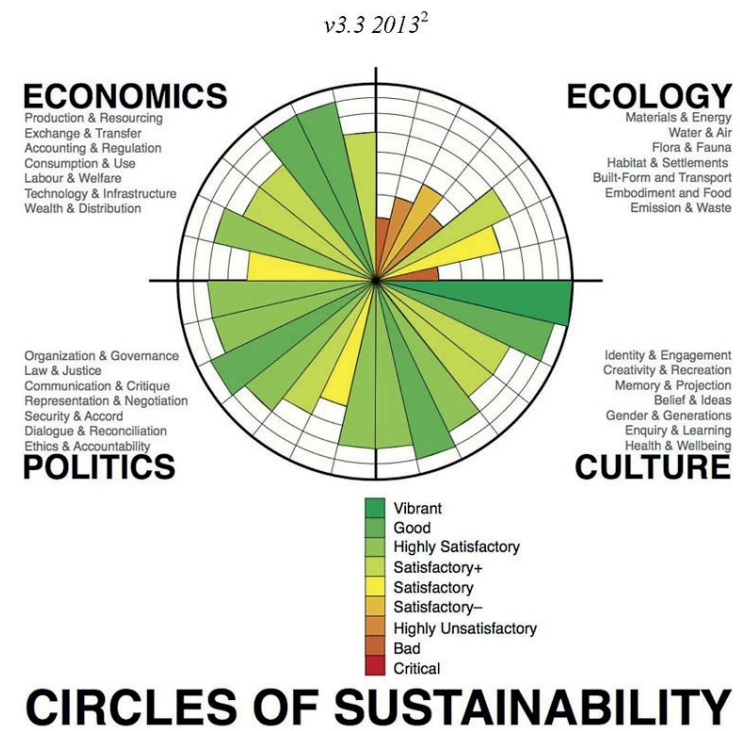

Figure 7. An example of a good approach to studying spatial sustainability [64] 


\section{Digital city, Smart City}

Smart cities are a very young creation and not fully defined. In the English-language literature, the following terms refer to smart cities and related spaces: digital city, smart city, information city, wire city, telecommunications, knowledge city, cyber-ties, flexicity, cyberville, teletopia, intelligent innovation environments. Concepts related to these new spaces are also linked to terms that emphasize a more social role in co-creating these places: electronic communities, smart communities, electronic community spaces. All this, in turn, is to lead to intelligent development, the so-called smart growth.

Generally, smart cities or fragments of such cities are to co-create smart communities - communities focused on creativity, innovation and environmental harmony . These goals are to be implemented by the individual characteristics of people who contribute to a given community, strongly supported by an IT system working (operating) in physical, institutional and virtual city spaces.

Smart cities are essentially based on two models. The first is innovation areas such as clusters, technology centers and innovation area systems. These structures are based on networks for information exchange, product exchange, innovative production and management systems. The second pattern is computer networks that form a kind of community.

The term smart city, introduced into the urban language, strengthened and broadened social awareness, knowing that the modern city is not only a physical space in the form of specific functions and forms, but also spatial relations between certain forms and functions, both in physical space and in virtual space [65].

From an economic point of view, these are often areas subsidized by the state or with specific tax advantages for technology transfer mainly to the industrial and manufacturing sectors. All logistic components are usually organized in the form of a network, the flexibility of which as well as technical and technological conditions are primarily focused on creativity. Knowledge transfer, the so-called Know-know is to be externalized in a specific product. Some processes are intentionally informal to give more freedom to investors and designers, which usually results into interesting innovative solutions. The quality of space is also subject to the intellectual stimulation of its users. This goal is to be achieved thanks to the large architectural diversity of objects and accompanying forms occurring in space. Physically important elements of smart cities are spaces: commercial, transactional, security, health, education, work, leisure and transport.

To emphasize their importance for modern society, they are promoted in mainstream media. This action is characteristic of the so-called Electronic commerce (e-commerce). These are the areas where problems are to be solved by acting as a virtual forum transferred to the real (physical) world. It is also a kind of "brainstorming" in which collective intelligence is to generate a better and innovative product. For this purpose, in many cases statistical data and benchmarking indicators are also used.

Although the term smart cities is relatively new, the values underlying the creation of this type of space have become clearly visible. The main value turns out to be innovation, followed by technology transfer. In the initial phase, the economy is not the dominant value. Innovation is directly related to creativity and ingenuity, independence and freedom in the intellectual sphere and to some extent in the spatial sphere [66].

The concept of smart city has not been included in any philosophical system so far and is based on such concepts as the smart philosophy or the smart grid philosophy. When describing various phenomena, mention is also made of the philosophy of open cooperation and open data transfer architecture. Undoubtedly, the basis of this philosophy is the cooperation of people and technological development, coinciding with the views on the technology development [67]. 


\section{Conclusions}

The significance of cities results from the effort that humanity puts in the process of their formation, construction and functioning, from the necessary sacrifices that are needed, for example, to harmonize the urban structure. The process of axiology becoming visible in the city is certainly a labor-intensive process; on the one hand, due to the fact that the city is a time-consuming material and creation, and on the other hand, due to the achievement of certain values, which is also a difficult process. Each fully formed city treated as a system is subject to transformations of the axiological system. These two systems - urban and axiological - interact and remain in a constant relationship resulting from the ongoing life, along with all its variability and dynamics, as well as changes in the perception of the world around us. Changes in the organization of societies largely affect the way cities function and form. There are cases in history when the guiding principles and norms of the division of urban areas have changed quite quickly as a result of the prevailing ideology and the related economy. At present, especially in Europe, we are dealing with extremely strong criticism of the previously recognized general values. The legitimacy of their existence and respect is questioned, which to some extent also applies to the existing principles of the city's functioning. Due to the values that constitute the city, their wealth, as well as the often unconscious importance of axiology in social life - this problem should be emphasized more clearly in the urban planning process.

Implementing values in an urban context raises two basic issues. The first one concerns the selection of a specific value system, the second one - conscious and creative use of them in planning activities. The starting point for spatial planning should be the common good as the guiding principle and value that shapes other behaviors and decisions in a special way. The spatial order we strive for is impossible to achieve without ordering the values and awareness of their impact on space. Even a slight specification of the axiological hierarchy can in many cases improve the design process and increase the transparency and clarity of decisions to be made.

Author Contributions: Conceptualization, R.B., M.Ł., J.D.; methodology, R.B.; investigation, R.B., M.Ł., J.D.; resources, M.Ł., J.D.; writing-original draft preparation, R.B., M.Ł., J.D.; writing-review and editing, R.B., M.Ł., J.D.; visualization, R.B.; supervision, R.B., M.Ł., J.D. All authors have read and agreed to the published version of the manuscript.

Funding: This research received no external funding.

Conflicts of Interest: The authors declare no conflict of interest.

\section{References}

[1] K. Ameriks, Kantian Subjects: Critical Philosophy and Late Modernity. Oxford: Oxford University Press, 2019.

[2] A. Noras, Rozumienie systemu w filozofii pokantowskiej. Katowice: Wydawnictwo Uniwersytetu Śląskiego, 2016.

[3] A. Noras, Problem psychologii w filozofii pokantowskiej. Katowice: Wydawnictwo Uniwersytetu Śląskiego, 2017.

[4] D. Brown and R. K. Crace, "Values in Life Role Choices and Outcomes: A Conceptual Model," Career Dev. Q., vol. 44 , no. 3, 1996.

[5] J. Hanson and B. Hillier, "The Architecture of Community," Archit. Behav. devoted to Sp. Syntax, pp. 249-271, 1987.

[6] D. Jerke, D. Porter, and T. Lassar, Urban Design and the Bottom Line: Optimizing the Return on Perception. Washington: Urban Land Institute, 2008.

[7] Platon, Państwo. Kęty: Wydawnictwo ANTYK - Marek Derewiecki, 2003. 
[8] M. Frajtag, "Pojęcie państwa w filozofii Arystotelesa," Uniwersytet Jagielloński, 2004.

[9] K. Nawratek, Miasto jako idea polityczna. Kraków: Korporacja ha!art, 2008.

[10] L. H. Sullivan, The tall office building artistically considered. Getty Research Institute, 1896.

[11] Le Corbusier, W strone architektury. Warszawa: Fundacja Centrum Architektury, 2012.

[12] J. Tarnowski, “Jeszcze o funkcjonalizmie w estetyce architektury: od Sokratesa do idei budynku totalnie ekoprzyjaznego," Estetyka i Kryt., vol. 24, no. 1/2012, p. 183, 2012.

[13] J. Dale, Ed., Schopenhauer, Philosophy and the Arts. Cambridge University Press, 1996.

[14] F. Nietzsche, Ecce Homo: How to Become What You Are. In The Anti-Christ, Ecce Homo, Twilight of the Idols, and Other Writings. New York: Cambridge University Press, 1908.

[15] P. A. Clarence, “Neighborhood Unit Concept)," Hous. Mech. Age, 1939.

[16] W. Korzeniewski, Normatyw urbanistyczny i mieszkaniowy 1974. Warszawa: Centralny Ośrodek Informacji Budownictwa, 1980.

[17] M. Baum, "The 1974 Urban Planning Norms in the Shaping of Green Areas on the Example of Białystok," Wydaw. Uniw. Przyr. we Wroctawiu, vol. 3, pp. 38-49, 2018.

[18] F. Hundertwasser, Mouldiness Manifesto Against Rationalism In Architecture, The Hunder. Berkeley, 1968.

[19] D. Kulas, “Dyskurs Filozofii Postmodernistycznej,” Uniwersytet Śląski, 2006.

[20] N. Royle, Jacques Derrida. London: Routledge, 2003.

[21] C. Jencks, The language of post-modern architecture. Londyn, 1991.

[22] "No Title," www.bryla.gazetadom.pl/. .

[23] “No Title," http://gadzetomania.pl. .

[24] F. Urban, Postmodern Architecture in Socialist Poland. Abingdon, Oxon; New York : Routledge, 2021.: Routledge, 2020 .

[25] J. Wujek, Mity i utopie architektury XX wieku. Warszawa: Arkady, 1986.

[26] "No Title," http://pl.wikipedia.org. .

[27] "No Title," http://www.charlesjencks.com. .

[28] M. Schwarz, "Interview with Leon Krier," Junge Freiheit, Berlin, 2020.

[29] K. Lenartowicz, “W poszukiwaniu złożoności miasta,” in Materiały Międzynarodowej Konferencji z okazji jubileuszu prof. S. Latoura: "Historia Miasto i Współczesność”, Szczecin, 2001, pp. 78-85.

[30] R. Venturi, Complexity and Contradiction in Architecture. New York: The Museum of Modern Art Press, 1966.

[31] "No Title," www.flikr.com. .

[32] M. Louis, “Transpositions: On the Intellectual Origins of Tschumi's Architectural Theory," Assemblage, vol. 11, pp. 22-35, 1990.

[33] Y. Gong, “The Influence of Deconstruction on Modern Architecture," J. Archit. Res. Dev., vol. 4, no. 6, pp. 4-7, 2020, doi: 10.26689/jard.v4i6.1668.

[34] N. Gildea, Jacques Derrida's Cambridge Affair Deconstruction, Philosophy and Institutionality. Rowman \& Littlefield Publishers, 2019.

[35] J. Llewelyn, Appositions of Jacques Derrida and Emmanuel Levinas. Indiana University Press, 2002.

[36] R. Koolhaas and B. Mau, S, M, L, XL. New York: The Monacelli Press Inc., 1998.

[37] D. I. Cunningham and J. Goodbun, "Propaganda architecture: interview with Rem Koolhaas and Reinier de Graaf," Radic. Philos., vol. 154, pp. 35-47, 2009.

[38] S. Petermann, J. Westcott, S. Trüby, and Harvard Graduate School of Design, Koolhaas. Elements of Architecture. Taschen, 2021. 
[39] M. Warchoł, “Architektura w ruchu," Niezbędnik Intel., no. 42 (2676), pp. 35-39, 2008.

[40] A. Christopher, Język wzorców. Miasta, budynki, konstrukcja. Gdańsk: Gdańskie Wydawnictwo Psychologiczne, 2008.

[41] J. Dudek, "Space for People in a Contemporary City - What Architectural and Town Planning Solutions Help in Shaping a Functional and Convenient Street," J. Civ. Eng. Environ. Archit., vol. 63, pp. 105-116, 2016, doi: 10.7862/rb.2016.253.

[42] J. K. Wiersma, L. Bertolini, and L. Harms, "Spatial conditions for car dependency in mid-sized European city regions," Eur. Plan. Stud., vol. 0, no. 0, pp. 1-17, 2020, doi: 10.1080/09654313.2020.1854691.

[43] J. Kron and S. Slesin, The Industrial Style and Source Book for The Home. New York: Clarkson N. Potter, 1978.

[44] A. Soyluk, Z. Y. İlerisoy, and E. Dadaş, “Evaluation of High-Tech Architectural Movement From 20Th Century To Today in Terms of Construction Materials and Structure," no. March, pp. 172-184, 2020.

[45] H. Lenk, “Challenges for a Pragmatic Philosophy of New Technologies,” Axiomathes, vol. 30, no. 6, pp. 649-665, Dec. 2020, doi: 10.1007/s10516-019-09456-9.

[46] O. Bina, A. Inch, and L. Pereira, "Beyond techno-utopia and its discontents: on the role of utopianism and speculative fiction in shaping alternatives to the smart city imaginary," Futures, 2020.

[47] "No Title," http://static.dezeen.com. .

[48] "No Title," http://theredlist.com. .

[49] B. Bartkowicz, "Ewolucja poglądów od strefy ochrony do równoważenia rozwoju struktury miejskiej ze szczególnym uwzględnieniem projektów dla Tarnowa," Czas. Tech. Archit., vol. z. 7-A, pp. 21-34, 2007.

[50] R. L. Kemp and S. Carl, Cities Going Green: A Handbook of Best Practices. 2011.

[51] S. Joss, "Eco-cities and Sustainable Urbanism," in International Encyclopedia of the Social E Behavioral Sciences, Elsevier, 2015, pp. 829-837.

[52] Y. Wu et al., “Design with nature and eco-city design,” Ecosyst. Heal. Sustain., vol. 6, no. 1, 2020, doi: 10.1080/20964129.2020.1781549.

[53] A. Marek-Bieniesz, “Za i przeciw realizacji wartości ekologicznych," in Ochrona środowiska społeczno-przyrodniczego w filozofii i teologii, J. M. Dołęga, J. W. Czartoszewski, and A. Skowroński, Eds. Warszawa, 2001, p. 282.

[54] "No Title," http://www.energiaidom.pl/328. .

[55] "No Title," https://www.google.pl/. .

[56] F. Caprotti and Z. Gong, "Challenging the eco-city," in Sustainable Cities in Asia, Abingdon, Oxon; New York, NY: Routledge, 2018.: Routledge, 2017, pp. 161-174.

[57] C. Villanueva, "An Ecofeminist Perspective on the Urban Envirnoment," in The Nature of Cities: Ecocriticism and Urban Environments, M. Bennett and D. T. Warfield, Eds. University of Arizona Press, 1999.

[58] M. Mąkólska-Tenold and M. Bąk, "Practical approach to the sustainable development in cities," Transp. Econ. Logist., vol. 79, pp. 23-37, Oct. 2018, doi: 10.26881/etil.2018.79.02.

[59] B. Maheshwari, V. Singh, and B. Thoradeniya, Balanced Urban Development: Is It a Myth or Reality? 2016.

[60] A. Papuziński, "Filozoficzne aspekty zrównoważonego rozwoju - wprowadzenie," in Problemy Ekorozwoju, vol. 1, Bydgoszcz: Uniwersytet im. Kazimierza Wielkiego w Bydgoszczy, 2006, pp. 25-32.

[61] M. Santamouris, Environmental Design of Urban Buildings. An Integrated Approach, 2006.

[62] M. Pesce, "Sustainable Retreat: A Concept that Denies Sustainable Development," Urban Times. .

[63] "No Title," http://www.muratorplus.pl. .

[64] “The Global Compact Cities Programme," http://citiesprogramme.com. . 
[65] M. Wdowiarz-Bilska, “Smart space - between a smart building and a smart city,” Środowisko Mieszk., vol. 19, no. January 2017, pp. 13-20, 2017, doi: 10.4467/25438700sm.17.022.7612.

[66] H. Allahar, “What are the challenges of building a smart city?," Technol. Innov. Manag. Rev., vol. 10, no. 9, pp. 38-48, 2020, doi: 10.22215/TIMREVIEW/1388.

[67] M. Nagenborg, T. Stone, M. González Woge, and P. E. Vermaas, Technology and the City, vol. 36. Cham: Springer International Publishing, 2021. 